Francis D

\title{
HIVISM': A PERVASIVE SYSTEM OF OPPRESSION
}

Dennis Francis is a Lecturer in the School of Education, Natal University. He teaches in the area of Social Justice in the Faculty's undergraduate, and postgraduate programmes. Faculty of Education, University of Natal

\section{INTRODUCTION}

This paper, structured in three parts, argues that the negative treatment meted out to people living with HIV/AIDS by those who are HIV negative or unaware of their serostatus, constitutes oppression. The writer draws on a qualitative study that explores the perceptions and experiences of nine individuals living with HIV/AIDS. In part one the terms stigma, prejudice, discrimination and oppression are unpacked. In the second part the writer describes the research strategy used to understand the participant's subjective experiences of prejudice and discrimination. Part three integrates the voices from the interviews together with the literature and empirical analysis. The following themes emerged: (1) Negative labels and stereotypes, (2) Unprovoked attacks on person and property, (3) Institutional discrimination and exclusion, (4) Internalised HIVism (people who accept the negative views of themselves experience feelings of guilt, shame and self-blame), and (5) Horizontal HIVism (people living with HIV/AIDS direct hostility and mistreat others who are HIV positive).

When I ask a class of postgraduate students to make a list of the myths, stereotypes or words they have used to describe people living with HIV/AIDS, they confidently express answers such as "House In Verulam (HIV)", "Umlazi 3" (named after a bus), "Isifo" (disease commonly found in hostels), "African sickness", "Punishment from God", "people who are immoral", "promiscuous", "drug takers", "prostitutes", "people who have sex with monkeys" and "Amagama Amathathu" (three words HIV). Evidence of such stereotypes, and stigmatisation is abundant, ranging from subtle prejudices to extreme discrimination. In fact, a growing body of evidence suggests that the HIV-related stigma and its associated prejudice and discrimination is a major stumbling block in addressing all aspects of HIV prevention, diagnosis, treatment and care (Brown, Trujillo \& Macintyre, 2001; Irwan, Millen \& Fallows, 2003). Understanding such stigma, prejudice and discrimination is therefore vital and necessary.

The literature on the HIV-related stigma and its repercussions on societies is growing, but the key issue addressed is how communities and individuals respond to the stigma (Aggledon, 2002; Barnett \& Whiteside, 2002; Govender, Bhana \& Pillay, 1992; UNICEF, 2001; Webb, 1997; Whiteside \& Sunter, 2000). A preliminary search for studies focusing on how people living with HIV/AIDS experience HIV-related stigma and its associated prejudice and discrimination in South Africa revealed a lack of appropriate research. It is worth quoting Sue O'Sullivan (2000:25) about the silence of people living with HIV/AIDS in the literature:

- $\quad$ "We are the women (and men) others write about, talk about, imagine. Our realities are diverse. Now we want to put our own voices, experiences, hopes and fears on the agenda. Our numbers are growing and its increasingly clear that we have to organise together to change the conditions of our lives."

This modest study does exactly this; it communicates the experiences and negative responses that people living with HIV/AIDS encounter from individuals and groups. 
In this paper I argue that the negative treatment meted out to people living with HIV/AIDS by those who are HIV negative or unaware of their serostatus constitutes oppression. To do this I start with a brief unpacking of some of the key concepts used in this paper. I then introduce the qualitative research design employed to interview the participants in this study. This will set the scene for me to turn to the voices from the interviews together with the empirical analysis.

\section{PREJUDICE, DISCRIMINATION AND OPPRESSION}

Every society has groups of people who are denied access to the rights and privileges enjoyed by some on account of physical, biological, social or other traits. Accordingly, every society has a set of up groups and a set of down groups. The down group members often receive negative treatment that may include negative beliefs (which may or not be expressed), exclusion, denial of basic human rights and overt acts of violence. The up group may use prejudice, stigmatisation and discrimination to maintain its control or power. Throughout this paper I use the terms prejudice, stigma, discrimination and oppression in very specific ways, hence it is probably a good idea for me to clarify from the outset what I mean.

Blumenfield and Raymond (2000) explain that to feel prejudice is to hold an adverse opinion or belief towards an individual or group; without just ground or before acquiring sufficient knowledge. For example, a person is said to be prejudiced if he or she believes that all people within a given group - say, people living with HIV - are sexually promiscuous. As a result, people living with HIV are prejudged not on fact but on the basis of stereotypes and misinformation.

Like prejudice, stigma has been described as an attitude that is deeply discrediting and used to set the targeted person or groups apart from the norm (Gillmore \& Somerville, 1994; Goffman, 1963). Goffman writes that the stigmatised individual is a person with a "spoiled identity" who is "rendered unworthy" by others (128). In the case of HIV/AIDS, a stigma may be applied to actual infection or to behaviours believed to lead to infection (UNICEF, 2001). Hence, HIV-related stigma is perceived as "a mark of shame" where the carrier of the virus is blamed, "devalued and significantly discredited" (Aggledon, 2002:8). Because HIV/AIDS first affected groups of people who were already marginalised, the stigma attached to HIV/AIDS is often layered upon preexisting stigmas of sexual conduct and drug use (UNICEF, 2001).

- The disease has been used to stigmatise various out groups. "Gay plague", women sex workers, foreigners, "those living across the lake", those people who are Black/Haitian/White/rich, "harijans", "tribal", "non-Han Chinese" and so on. People have used all the labels, and many more, to identify "those who are to be" stigmatised (Barnett \& Whiteside, 2002:66).

HIV-related stigma becomes so etched in the social identity of the person living with HIV/AIDS that it plays into and reinforces existing social inequalities.

When feelings of stigma, prejudice and stereotypical beliefs move into the realm of behaviour, the result is discrimination. Blumenfield \& Raymond (2000) define discrimination as the negative treatment of an individual or group of people as it denies individuals or groups equal treatment. For example, it would be discriminatory when people living with HIV/AIDS are denied access to certain jobs such as teaching on the basis of HIV-related stigma and prejudice. While terms such as "prejudice", "stigma" and "stereotypes" are mostly used to describe the attitudes of individual people in their personal interaction with other individuals, "discrimination" and "oppression" are generally used to convey the working of a larger social system. 
The term "oppression" rather than "discrimination", "bias", "prejudice" or "bigotry" is used to emphasise the nature of social inequality.

- Oppression signifies a hierarchical relationship in which the dominant group benefit, often in unconscious ways, from the disempowerment of subordinated or targeted groups (Bell, 1997:4).

Adams, Bell and Griffin (1997) use certain key concepts in their approach to oppression. Oppression is explained as dividing people into two groups - a privileged up group (agents) and a subordinate down group (targets). Through internalised domination, agents act in ways that express internalised notions of entitlement and privilege, while targets through internalised subordination knowingly, but not necessarily voluntarily, go along with their own mistreatment to survive or to maintain some status, livelihood or other benefits. In order for social oppression to exist, Hardiman and Jackson (1997:17) identify four conditions:

- Firstly, the one up group has the power to define and name reality and to determine what is normal, real or correct. Secondly, harassment, discrimination, exploitation, marginalisation and other forms of differential treatment are institutionalised and systemic. Thirdly, psychological colonisation of the target group occurs through socialising the oppressed to internalise their oppressed condition and collude with the oppressors' ideology and social system. Finally the target group's culture, language, history is misrepresented, discounted or eradicated and the dominant group's culture is imposed.

Young (2000) lists five conditions as a means of determining whether a group is oppressed. She names "five faces of oppression" as a means to determining whether a group is oppressed: exploitation, marginalisation, powerlessness, cultural imperialism and violence. Young (2000) explains that any one of the five characteristics is sufficient for calling a group oppressed.

Using the framework outlined by Hardiman and Jackson (1997) and Young (2000), I will argue that the negative treatment meted out to people living with HIV/AIDS by people who are HIV negative and those who are unaware of the HIV status constitutes oppression. To do this I draw on a qualitative study that explores the perceptions and experiences of nine individuals living with HIV/AIDS and the negative responses they encounter.

\section{RESEARCH STRATEGY}

The researcher in this study did not look for numbers of incidents or for participants who have experienced HIV/ AIDS-associated discrimination and prejudice. Instead, he attempted to establish whether discrimination and prejudice are a reality for the nine participants living with HIV/AIDS. All nine participants in this study self identified as being HIV positive and formed part of a support group run by a non-governmental organisation (NGO) in the North Durban area. The sample included four African women, one White woman, two African men, a White man and an Indian man. The participant's ages ranged from 26 to 39. In order to understand the participants' experiences, a qualitative approach reflecting the phenomenological paradigm was utilised. This approach allowed the researcher to capture what really goes on in the participants' everyday lives by incorporating the context in which the participants operate, as well as their frame of reference.

The researcher in this study used focus group discussion as is common in support group environments. The focus group discussions are similar to the client-centred therapy approaches used by Rogers (1990), where the values of listening, empathy, unconditional positive regard, selfdetermination, respect and confidentiality are paramount. During the focus group discussions, the role of the research/facilitator became almost diluted. The participants agreed and disagreed with 
each other, filled in gaps in each other's stories, passionately supported narratives that sounded familiar, and at times merely reflected silently as they related their experiences of HIV-related stigma and its associated prejudice and discrimination. It was evident that the participants were using their frame of reference rather than mine. The following themes emerged from the study: (1) Negative labels and stereotypes, (2) Unprovoked attacks on person and property, (3) Institutional discrimination and exclusion, (4) Internalised HIVism (people who accept the negative views of themselves and experience feelings of guilt, shame and self-blame), and (5) Horizontal HIVism (people living with HIV/AIDS direct hostility and mistreat others who are HIV positive).

\section{Negative labels and stereotypes}

All the participants in the study reported that they were often negatively labelled and/or stereotyped. The stereotypes were linked to the existing HIV-related stigma and prejudice and loaded with religious and sexual nuances:

- $\quad$ "Although the people in my church have been supportive, some of them tell me that I am HIV positive because I do not have enough faith."

- $\quad$ "One woman told me that she is always praying for me, that I must seek repentance and will be redeemed for my immorality."

- $\quad$ "I am tired of hearing that we are being punished by God for straying from his ways and that we are witnessing another Sodom and Gomorrah."

- $\quad$ "I was giving a talk to a group of workers about HIV. These people were saying to me that the only way I could be HIV positive is if I was sleeping with many men or I was having sex with the truck drivers."

One of the means of establishing dominance and power in the system of oppression is the naming of the targets by the up group. People who are HIV negative or unaware of their serostatus have the power to define and determine what is normal, real or correct. Consequently, there is the tendency by the agent group (those who are HIV negative or are unaware of their HIV status) to stereotype people living with HIV/AIDS as sinners, immoral beings and sexually promiscuous. With regards to stereotypes, Pharr (1988:9) suggests that "...stereotyping contributes to another common element of oppression: blaming the victim for the oppression."

- In order for oppression to be thoroughly successful, it is necessary to involve the victims in it. The victim lives in an environment of negative images (stereotypes) and messages, backed by violence, victim hating and blaming, all of which leads to low self-esteem and self-blame in the victim. The goal of this environment is to lead the victim to be complicit with her/his victimisation: to think that it is deserved and should not be resisted.

The assumption made by the agents is that all people living with HIV/AIDS have been immoral and/or sexually deviant and therefore deserve their predicament. This assumption is evident in the literature globally where powerful imagery, metaphors and euphemisms are used to define people who are HIV positive or living with AIDS.

A UNICEF (2001:9-24) study on the extent of perceived and enacted HIV/AIDS-related stigma conducted in four countries reported that people living with HIV/AIDS were viewed as deviant, as a stereotyped "other" and as different from the dominant group. In the light of the UNICEF (2001) study, people living with HIV/AIDS in Zambia were associated with socially perceived immorality and promiscuity and labelled with terms such as zayero (prostitutes) and mombwe (men having sex with many women). Similarly, in India people living with HIV/AIDS were 
frequently associated with immoral behaviour and labels such as "those with dirty blood", "those who have many affairs" and "worms from the gutter" were common. Offensive labels such as Tvarj konchennaya (creature) and zhivotnoje (animal) were common in the Ukraine. In Burkina Faso the HIV-related stigma carried clear religious and sexual connotations. HIV/AIDS was viewed as a "curse from God", and people living with HIV/AIDS were likened to "sinners", and "Disciples of Satan" (UNICEF, 2001:22-24). Reddy and Louw (2002:90) report similar stereotypes in their study. In their assessment of perceptions and sexual practices of young African gay men, popular myths such as AIDS is a disease designed by God to kill evil and punish the corrupt world were prevalent.

The stereotypes and negative labels cited in the literature (Barnett \& Whiteside, 2002; Reddy \& Louw, 2002; UNICEF, 2001; Webb, 1997) are no different from the ones named by my class of postgraduates or by the nine participants in this study. These labels devalue people living with HIV/AIDS and become so ingrained that they are seen as uncontestable.

\section{Unprovoked attacks on person and property}

A second theme that emerged in this study is the range of abuse experienced by the participants because of their seropositive status. Six of the nine participants reported that they have been physically beaten, harassed, threatened with violence or abandoned. Family members, friends and people they had never met before were involved in directing physical violence and hostility towards participants. Experiences of violence at the hands of close family included:

- $\quad$ "He (boyfriend) did not say anything. He just left. He returned at about eleven and was drunk. He then started hitting me. My mouth was bleeding. He said that I was going to give him the virus. He threatened to burn me so that I will not infect him or anyone else."

- "My sisters said that I must go and die somewhere else. I must not bring my shame into the house. They said that I deserved it and that is what I get from sleeping with prostitutes."

- "They threw all my stuff into the garage. I have stayed in the garage since."

- $\quad$ "My father said that I must never come back to his house and if I did he will shoot me. He did not want to expose his family to my disease."

- $\quad$ "Some participants reported that they also experienced violence and harassment from people other than family and friends."

- $\quad$ "I was getting into the taxi. This man saw the sores on my legs. He started shouting at me and telling everyone that I have AIDS. Another woman in the taxi was supporting him and saying that I must get out of the taxi. Just before the taxi could leave the man punched me on my ear."

- $\quad$ I was sick and I was staying at my mother's house. I heard some people outside. They were asking my mother why she was keeping an AIDS person in her house. They wanted to come in and see how I was suffering. My mother would not let them in and closed the door. A few minutes later someone threw a large stone through the window."

Physical violence and systematic harassment has been a common experience for many people living with HIV/ AIDS. In a study ${ }^{2}$ conducted by Webb (1997) to determine the attitudes towards people living with HIV/AIDS (PWA) participants were asked to answer the question "What should

2 The field sites for the study covered the following geographical areas: The province of Mphumulanga, Soweto, Natal Midlands in South Africa, together with the village of Okatna, Namibia (Webb, 1997:57) 
happen to people with AIDS?" The participant's responses were classified into three groups: "kill", "isolate" and "care" (Webb, 1997:168). The rationale for wanting PWAs killed included:

- "They must get what they deserve...shoot them"; "give them fatal injections for AIDS"; "kill that person because he might transmit the disease to other people"; "shoot them, there is no cure...you can do nothing for them" (Webb, 1997:169).

The desire to kill PWAs is a severe response, but is indicative of very high levels of prevalent stigma and prejudice. These negative attitudes are a barrier to prevention and make disclosure to partners, families and communities extremely difficult. The most tragic example of this was the death of Gugu Dlamini. Newspaper reports state that Gugu Dlamini was stoned and beaten to death after she had spoken out about her HIV status. Neighbours accused Gugu Dlamini of shaming the community by revealing her HIV status (Sunday Independent, August 14, 1999). Mpho Motloung is another example of a person killed because of her seropostive status (Sowetan, August 23, 1999).

In addition to experiencing systematic harassment and violence, people living with HIV/AIDS also live with the knowledge that they must fear thoughts of social and geographical isolation. Two respondents in this study reported:

- $\quad$ "One of the men pulled me by my arm and said that I must not walk away when he is talking to me. He said that he knows that I have AIDS and that he thinks that all people with AIDS should be buried in a big hole."

- $\quad$ "He said that they should just put us all on Robben Island so that we can infect and kill each other."

The desire to see PWA isolated both socially and geographically has been a common response to the epidemic. The isolation of PWA has been attempted in Bangladesh and Cuba, but the desire for quarantine appears to be universal (Webb, 1997:173). The isolating of PWAs was a common theme in the UNICEF (2001), study where people in the different countries emphasised physical distance between themselves and people suspected of having a positive serostatus. In a South African study conducted with family planning clinic attendees in Johannesburg, 68.2\% of respondents felt that AIDS patients should be isolated in hospital wards (Govender et al. 1992). In Webb's study (1997:171) the desire for isolation of PWAs was very evident.

They should be placed in a concentration camp "...placed under guard"; "isolated from healthy people"; "Isolated in hospital; kept there until they die...kept away from the community"; they shouldn't live with normal people; "a place should be built for them"; "a place of their own should be built, so that they may get encouragement from other people with the virus... they'll encourage each other".

The desire to isolate people living with HIV/AIDS strips them of the value they are able to contribute to a society and serves to create a dualistic society which acts to perpetuate categories of superior and inferior, dominant and subordinate, and up and down groups.

\section{Institutional discrimination and exclusion}

While the two themes discussed above describe individual oppressive attitudes and behaviours, the participants in this study also encountered institutional oppression. Because of their serostatus, participants reported experiencing negative responses in the family, hospitals, schools, work place and religious institutions. In the family HIV-associated prejudice and discrimination were common. 
- $\quad$ "My aunty labelled my plate and cup with CF. She did this so that no one else would be able to be infected."

- $\quad$ "I had to wash my clothes, sheets and anything I used separately from the so that no one else would be exposed to my germs."

- "When they (family) would use the toilet after me, they (family) would use Detol to clean the seat."

- $\quad$ My sisters would just open the door of the garage, and put my food on the floor. They would complain and be disgusted at the way I smelt."

Similarly, in hospitals HIV-related stigma and the related prejudice and discrimination were reported.

- $\quad$ I called the nurses but they would not help. When a nurse finally came she said that I deserved to be in pain because I knew that I was HIV positive and should not have got pregnant."

- $\quad$ The doctor said that I should rather go back to the farm, because there was nothing he could do. When I went back to the hospital, the nurses said that I was wasting their time and that I was just taking up bed space."

- $\quad$ I couldn't see properly because the meningitis affected my eyes. When I needed to go to the toilet the nurses would not help me. When I messed my bed, they would shout at me."

The participants' experiences at home and in hospitals describe the high prevalence of HIV-related stigma and prejudice, where it is believed that people living with HIV/AIDS deserved their condition. By attributing blame to people living with HIV/AIDS, the agent group is able to discredit, devalue and characterise people living with HIV/AIDS as unworthy. This also allows the agent group to justify institutional discriminatory practices.

The participants in this study reported that when they were open about their serostatus in the work place, they experienced exclusion, discrimination and termination of working contracts. One participant reported:

- $\quad$ "When I returned from hospital my boss said to me 'Why don't you just resign and rest and let someone more able do the work'."

Another expressed how her contract was terminated in the hospital:

- $\quad$ "My boss came to the hospital with all the papers to terminate my services. He saw how sick I was and he left. Two days later I was asked to attend a meeting and was given three months notice."

While HIV is not readily transmitted in the majority of workplace environments, numerous employers have used the supposed risk of transmission as an excuse to terminate or refuse employment to those who are HIV positive (Aggledon, 2000; Omangi, 1997). Some employers have opted to get around the demands of providing medical and pension benefits to people who are living with HIV/AIDS by denying employment (Whiteside 1993). In the Ukraine people living with HIV reported that when their serostatus was known, they experienced rejection by colleagues and excuses were found to dismiss them. Some Ukrainian employers enforced pre-employment testing as part of their recruitment process, refusing work to those who were HIV positive. (UNICEF, 2001:19-21). In South Africa two flight attendants were denied employment on the basis of their seropositive status. In one of the cases the airways company admitted 
unconditionally that the exclusion of the applicant for the post of cabin attendants was on the grounds of his HIV status (Whiteside \& Sunter, 2000).

Participants in this study reported that when they first disclosed their serostatus in the work place, colleagues expressed that they will not discriminate against them. However, as time lapsed participants noted different behaviour:

- $\quad$ "They would talk very softly with one another but when I joined they would keep quite. I knew they were talking about me' and 'I noticed that none of the other colleagues were using the toilet that I was using and that my teacup was placed far from the other cups."

Although HIV is not readily transmitted in workplace settings, agents with ingrained prejudice and ignorance discriminate against and stigmatise people living with HIV/AIDS. Often the discriminatory attitudes by the agents force people living with HIV/AIDS to depart from the work place as a form of self-preservation. One participant reported:

- $\quad$ "I just could not take the gossiping, separate teacups and the toilet issue any more. I was just getting myself depressed. If I had stayed on I would have probably died of depression."

This is typical of how people living with HIV/AIDS, as a social group, are expelled by the agents from useful social and economic participation and inevitably are subjected to material deprivation.

\section{Internalised HIVism (people who accept the negative views of themselves and experience feelings of guilt, shame and self-blame)}

People living with HIV/AIDS who accept the negative views and treatment of themselves and of those who have a seropositive status are involved in internalised oppression or internalised HIVism. Internalised HIVism refers to the feelings of shame, self-blame and guilt that people living with HIV/AIDS experience when they internalise the negative responses and reactions from others. People who have been socialised in an oppressive environment and who accept the up group's ideology about them learn to accept a definition of themselves that is hurtful and limiting (Hardiman \& Jackson, 1997). Participants reported feeling ashamed, sinful, self-hatred, and guilt; they blamed themselves and even contemplated suicide.

- "When I first learnt that I was HIV positive, I cried. I remember looking at myself in the mirror and felt like a sinner. I asked God why was he punishing me?"

- $\quad$ "I felt ashamed and guilty when my sister said that I deserved what I had (HIV). For a long time I believed that I was a bad person and that I deserved the punishment."

- $\quad$ "I felt as though I was a burden to my family. That I had brought shame and disgrace to my mother and father."

- $\quad$ "I thought of killing myself then my family would have said that I died from suicide and not from HIV and they still would be proud."

Response such as the above indicate how people have internalised HIVism. By accepting many of the stigmas and stereotypes people living with HIV/AIDS (PWA) experience self-blame, lack of self-worth and depression. Similar findings were reported in the UNICEF (2001:9-24) study, in which people living with HIV/AIDS reported:

- "Feelings of remorse and guilt", "being fearful of disclosure", "expressed fears of becoming alcoholics and drug users", "being considered as wicked and cruel witches", "accused of 
bringing shame, dishonour and destruction" and "men also tended to be suicidal, often questioning the meaning and value of life."

This is indicative of ways in which PWAs have been socialised in an oppressive society and who accept the up group's ideology about themselves. PWAs have learned to accept a definition of themselves that is hurtful and limiting. They think, feel and act in ways that demonstrate the devaluation of themselves by their group. By internalising their oppression, PWAs erroneously accept that they are the problem. They are at one and the same time themselves and their oppressors whose consciousness they have internalised (Freire, 1970:32-33).

\section{Horizontal HIVism (people living with HIV/AIDS direct hostility and mistreat others who are HIV positive).}

When PWAs direct hostility, mistreat or blame members of their own group on the basis of their own internalised oppression, the term horizontal oppression or horizontal HIVism is used. This horizontal dynamic creates divisions between targeted groups and helps to maintain the oppression. The interviews were marked by a number of references to horizontal HIVism, especially when the participants first realised they were HIV positive.

- $\quad$ "I went home to the farm. There was a funeral and the people were talking about the person who had died from AIDS. Nobody wanted to go near the body. I kept quiet and did not say anything. Only the two brothers carried the coffin. I stood with the others. I even joined the conversation talking bad things about how the person died. I was scared that everyone would know that I was HIV positive."

- $\quad$ "Someone else was diagnosed with HIV in our extended family. At that stage none of them knew that I was HIV positive. I said to my mother 'Why does she have to sleep around' and 'Can't she just sleep with one person.' My mother and sister were also agreeing with me."

- "When I first realised I was HIV positive I would speak very aggressively about those who were HIV positive so that those around me would not focus on me."

- $\quad$ "I once asked someone who was very thin 'Why are you so thin? Do you have the virus?' The person was so embarrassed. I asked her even louder 'Are you practising safe sex?' Later I felt bad. I don't know why I did that."

Pharr (1988:10) explains why the horizontal dynamic exists:

- $\quad$ If one has learnt self-hatred because of one's membership in a 'minority' group, then the disrespect and hatred can easily be extended to the entire group, so that one does not see hope or promise for the whole. It is safer to express hostility towards other oppressed peoples than toward the oppressor."

Hence, people living with HIV/AIDS respect and identify with those who are in power who make up the norm, and at the same time display hostility and distrust towards those like them who are different from the norm. By people living with HIV/AIDS directing hostility towards and displaying reluctance to associate with other PWA, the focus and attention is removed and diverted from the self. One participant responded: "By blaming and focusing on others who are HIV positive no one would point a finger at me". Through horizontal oppression, experiences of prejudice, discrimination and stigma are avoided and redirected at other targets. In this way PWAs collude with their own oppression. 


\section{CONCLUSION}

I have argued that HIVism is a pervasive system of discrimination and exclusion that oppresses people living with HIV/AIDS. The criteria outlined by both Hardiman and Jackson (1997) and Young (2000) to determine whether a group is oppressed captures the experiences of the participants in this study. Like racism, sexism, heterosexism and other forms of oppression, people living with HIV/AIDS constitute an oppressed group and experience oppression at the individual, institutional and societal level. The manifestation of HIVism creates a climate of harassment and discrimination that forces many living with HIV/AIDS to live their lives as second-class citizens. Consequently, many people living with HIV/AIDS still live in fear of discovery because of the prevalent stigma and the associated prejudice and discrimination.

\section{REFERENCES}

ADAMS, M., BELL, L.A. \& GRIFFIN, P. (eds) Teaching for diversity and social justice: A source book. New York: Routledge.

AGGLEDON, P. 2000. Comparative analysis: Research studies from India and Uganda: HIV and AIDS related discrimination, stigmatisation and denial. Geneva: UNAIDS.

AGGLEDON, P. \& PARKER, R. 2002. A conceptual framework and basis for action: HIV/AIDS stigma and discrimination. Geneva: UNAIDS.

BARNETT, T. \& WHITESIDE, A. (eds) 2002. Aids in the Twenty-First Century: Disease and globalisation. MacMillan: Palgrave.

BELL, L.A. 1997. Theoretical foundations for social justice education. In: ADAMS, M., BELL, L.A. \& GRIFFIN, P. (eds) Teaching for diversity and social justice: A source book. New York: Routledge.

BLUMENFELD, W.J. \& RAYMOND, D. 2000. Prejudice and discrimination. In: ADAMS, M., BLUMENFELD, W.J., CASTANEDA, R., HACKMAN, W.H., PETERS, M.L. \& ZUNIGA, X. (eds), Readings for diversity and social justice. New York: Routledge.

BROWN, L., TRUJILLO, L. \& MACINTYRE, K. 2001. Interventions to reduce HIV/AIDS stigma: What have we learned? Tulane University: Horizons Program.

FREIRE, P. 1970. Pedagogy of the oppressed. New York: Seabury.

GILLMORE, N. \& SOMERVILLE, M. 1994. Stigmatisation, scapegoating and discrimination in sexually transmitted diseases: Overcoming 'them' and 'us'. Social Science and Medicine, 39(9):1339-1358.

GOFFMAN, E. 1963. Stigma, notes on the management of a spoilt identity: London: Pelican.

GOSTIN, L.O. \& LAZZAINI, Z. 1997. Human rights and public health in the AIDS pandemic. New York: Oxford University Press.

GOVENDER, V., BHANA, R. \& PILLAY, A. 1992. Perceptions and knowledge about AIDS among family planning clinic attenders in Johannesburg. South African Medical Journal, 81(1):71-74.

HARDIMAN, R. \& JACKSON, B. 1997. Conceptual Foundations for Social Justice Courses. In: ADAMS, M., BELL, L.A. \& GRIFFIN, P. (eds) Teaching for diversity and social justice: A source book. New York: Routledge. 
HEREK, G.M. 1990. Illness, stigma, and AIDS. In: COSTA, P.T. \& VAN DEN BOS, G.R. (eds) Psychological aspects of serious illness: Chronic conditions, fatal diseases, and clinical care, Washington, D.C: American Psychological Association.

IRWAN, A., MILLEN, J. \& FALLOWS, D. 2003. Global AIDS: Myths and facts. Cambridge: South End Press.

OMANGI, H.G. 1997. Stigmatisation and discrimination in the context of HIV and AIDS in Kenya, Newsletter of African Network on Ethics, Law and HIV, No. 3.

O'SULLIVAN, S. 2000. Uniting across boundaries - HIV positive women in global perspective in Agenda, No. 44.

PHARR, S. 1988. Homophobia: A weapon of sexism. Inverness, CA: Chardon Press.

PREGGE, J.V. 1995. Living with Loss in the Best Way We Know: AIDS and Gay men in Cape Town. In: GEVISSER M. \& CAMERON, E. (eds) Defiant Desire. New York: Routledge.

REDDY, V. \& LOUW, R. 2002. Black and gay: perceptions and interventions around HIV in Durban in Agenda, No. 53.

ROGERS, C. 1990. Client-centred therapy. In: KIRSCHENBAUM, M. \& HENDERSON, V.L. (eds) Carl Rogers dialogues. London: Constable.

SOWETAN, Man kills wife, her mom, self, 23 August 2000.

SUNDAY INDEPENDENT, Dlamini case dropped for lack of proof, 14 August 1999.

UNICEF 2001. Stigma, HIV/AIDS and prevention of mother-to-child transmission: A pilot study in Zambia, India, Ukraine and Burkina Faso. London: UNICEF.

WEBB, D. 1997. HIV and AIDS in Africa, Pluto Press: London.

WHITESIDE, A. \& SUNTER, C. 2000. AIDS: The challenge for South Africa, Cape Town: Tafelberg Publishers.

WHITESIDE, A. 1993. The impact of AIDS on industry in Zimbabwe. In: CROSS, S. \& WHITESIDE, A. (eds) Facing up to AIDS, the socio economic impact in Southern Africa. New York: St Martin's Press.

YOUNG, I.M. 2000. Five faces of oppression. In: ADAMS, M., BLUMENFELD, W.J., CASTANEDA, R., HACKMAN, W.H., PETERS, M.L. \& ZUNIGA, X. (eds) Readings for Diversity and Social Justice. New York: Routledge.

\section{ACKNOWLEDGEMENTS}

I would like to thank Emma Francis and Paulette Dalphes for their contribution to and feedback on this paper. 